\title{
MECHANISMS AND MEANS OF TRAINING IN FINANCIAL AND ECONOMIC ISSUES FOR MASTERS IN MANAGEMENT OF EDUCATIONAL INSTITUTIONS
}

\section{Kuzmenko Yu. A.}

\section{INTRODUCTION}

In the current context of reforming higher education, our country faces the need to improve the quality of training academic elite, which includes future leaders of educational institutions currently trained in Management (Specialty 073). At the same time, the challenges of informational and capitalist society require new approaches and principles for solving the problems of management of institutions and organizations in the field of education and vocational training, in particular certain objectives and commitments should be changed.

One of the points is of utmost importance, namely the fact that educational institution needs a modern leader, able not only to "survive" in today's competitive conditions and maintain sustainable financial independence of educational institution, but also direct all the efforts and resources at the development and prosperity of this institution in the long term, which will give more freedom of action and space for the implementation of the latest, creative ideas in education. Consequently, heads of educational institutions face the problem of providing multichannel financial support and reasonable allocation of funds.

At present, managerial financial and economic activity (hereinafter FEA) is built on the legal and regulatory framework of the economy, based on such documents as the Constitution of Ukraine, the Laws of Ukraine "On Education", "On Higher Education", "On General Secondary Education ", Presidential Decrees, the Decrees of the Verkhovna Rada and the Cabinet of Ministers in the field of education, decisions of the Constitutional Court, rules, regulations and instructions of the Ministry of Education and Science, Regional City and District Administration, Taxpayer Code of Ukraine, etc.

Meanwhile, the documents mentioned are too abstract to determine managerial financial and economic activities in a capitalist system. As a result, the issue of training future managers of educational institutions is 
in the priority on the agenda in general, and the formation of their entrepreneurial culture, in particular.

From various perspectives different authors described, explained and analyzed efficient financial and economic activity of heads of educational institutions, but mostly on a spontaneous, chaotic, uncoordinated basis, and a lot of issues have remained unclear. Among the scholars involved in the development and implementation of standards for the training of masters in management of educational institutions, we note significant asymmetry in relation to the problem of increasing the role of economic aspect.

Until recently, the main component of the branch standard of higher education (educational-professional program and educational qualification characteristic), guiding universities that train masters in management of educational institution, were developed by the specialists of the Ministry of Education and Science of Ukraine. For these reasons, the analysis of the documents is of both theoretical and practical interest.

It shows that managerial economic component as a prerequisite for the successful management activities in professional training has been accorded low priority.

Therefore, in order to increase economic competence of educational institution heads, some adjustments should be made to professional training curriculum, namely: to pay more attention to the subjects that shape managers' abilities to finance cash flows, save school resources, supplement staffing resources and strengthen material potential, as well as to provide an impetus for identifying leadership skills of future masters in management of educational institution in the process of practical training and internship.

\section{Modern Entrepreneurs Expertise in Professional Training of Managers of Educational Institutions}

The analysis of the training programs for future masters in management of educational institutions suggests that the current version of professional education does not pay much attention to the issue of the development and formation of entrepreneurship culture and their capacity for financial and economic activity in educational institutions. As a result of such low priority of entrepreneurship in education sector, educational institutions often experience stagnation and staff 
demotivation, which is unacceptable in the context of capitalist-oriented standards of living.

Among the circumstances that obviously affect the ability to overcome this disadvantage is financial and economic training for students majoring in management through updating certain courses in their curriculum.

Among the 15 recommended courses included in the recent version of educational-professional program (hereinafter - EPP) for students getting master's degree in specialty 8.000009 "School Management" of the Branch Standard of Higher Education of Ukraine ${ }^{1}$, developed by a group of specialists of the Ministry of Education and Science of Ukraine in 2006, we can specify "Financial and Economic Activity" and "Audit and Evaluation of Management" with modules, reflecting the possibility of masters' acquiring economic and financial education.

Unfortunately, the period of validity for specialty state standards expired, thus, institutions of higher education, using the right of more free academic freedom in training programs, significantly reduced, and sometimes completely abandoned the above specified disciplines in favor of purely pedagogical and administrative subjects.

Such reduction can be explained by internal university struggle for the teaching load, which correlates with salaries of academic and pedagogical staff.

Our selective analysis of educational programs and interviewing the guarantors of educational programs confirm this idea and give a possibility to conclude that financial and economic training of future masters in management of educational institution deteriorated significantly, showing tendencies of reduction.

Thus, in Semen Kuznets Kharkiv National Economic University in the EPP, the course "Management of Financial and Economic Activity" is artificially combined with the legal aspects of management, as can be seen from the title: "Legal, Financial and Economic Aspects of Management of Educational Institution". Meanwhile, even a superficial analysis of the content of this course shows that it is not directly related to the person's ability to freely navigate in the aspects of purposefulness, motivation, planning, organization, ordering, control, exchange,

1 Освітньо-професійна програма підготовки магістра за спеціальністю специфічних категорій 8.000009 "Управління навчальним закладом". Київ: Міністерство освіти і науки України, 2016. 61 с. 
material, intellectual-informational, personnel, aesthetic, image and other values both inside educational system and externally. Of course, certain competencies seem rather weird without any connection with the name of the course. For clarity, we give a quote from EPP, where the final competence of the course is presented: "the ability to manage developing educational institution (establishment)"; "the ability to conduct highly effective management, even in emergency situation"2. As we see, the authors of EPP do not reveal the essence of the course, nor do they tackle legal management aspects, legal restrictions for managers, except for the name, the FEA line is not followed.

Further analysis of EPP for another specialty (namely, "Management of Organizations and Administration"), developed by experts of Semen Kuznets Kharkiv National Economic University, resulted in certain positive aspects that are worthy of extrapolation. In particular, we find valuable the content of such courses as: "Financial Management"; "Reengineering Business Processes"; "Enterprise Potential Management", which provide the development of the following abilities:

- ability to develop efficient functionally oriented schemes of financial management, enterprise long-term and short-term financial policy, to assess entrepreneurial, investment and financial risks;

- ability to develop both short-term and long-term budgets, as well as various other forms of financial plans, to assess effectiveness of financial activities; ability to manage capital and investment portfolio, assess their profitability;

- ability to substantiate a complex of managerial decisions on creation, successful operation, support and development of enterprise potential as a system;

- the ability to identify opportunities and develop measures to mobilize them ${ }^{3}$.

This list of competencies clearly demonstrates that such training for managers has become a reliable basis for future heads of educational institutions since 2015, in compliance with the decision of the Ministry

${ }^{2}$ Освітньо-професійна програма підготовки магістра за спеціальністю 073 “Менеджмент". Харків: Харківський національному економічному університеті імені Семена Кузнеця, 2016. 79 с.

${ }^{3}$ Там само. 
of Education and Science to introduce a new system of ciphers and specialty titles in Ukraine ${ }^{4}$.

Review of similar EPP in other universities in the country shows similar situations. For example, National University of Bioresources and Natural Resources of Ukraine included in the curriculum "Financial and Economic Management" and added "Strategic Management", which offers studies of external environment evaluating, organizational goals, taking decisions aimed at creating and maintaining competitive advantages to provide business profits in the long run ${ }^{5}$.

The next institution that we have considered is Ukrainian Engineering and Pedagogical Academy, which replaced the courses "Management of Financial and Economic Activities" and "Audit and Evaluation of Management" with one - "Financial Management in Education". Although, in our opinion, such competence as "ability to plan and manage educational institution by means of innovative technologies"6 seems rather strange, it needs at least a strategic goal for effective cash flows financing and efficient functioning of educational institutions.

We see a similar situation in Kherson State University, which also lacks the abovementioned courses, but introduced "Business Organization and Planning", although the competence, stated in EPP "to establish the criteria for further development of organization, to develop and implement relevant strategies and plans"7 is not entirely consistent with the content of the course and appeared to be rather superficial.

${ }^{4}$ Про особливості запровадження переліку галузей знань і спеціальностей, за якими здійснюється підготовка здобувачів вищої освіти: наказ Міністерства освіти і науки від 06.11.2015 №1151 України 2015 року № 266. URL: https://imzo.gov.ua/ 2015/11/06/nakaz-mon-vid-6-11-2015-1151-pro-osoblivosti-zaprovadzhennya-pereliku-galuzeyznan-i-spetsialnostey-za-yakimi-zdiysnyuyetsya-pidgotovka-zdobuvachiv-vishhoyi-osvitizatverdzhenogo-postanovoyu/ (дата звернення: 30.07.2018)

5 Освітньо-професійна програма «Управління навчальним закладом» за спеціальністю 073 «Менеджмент». Київ: Національний університет біоресурсів i природокористування України, 2018. 28 с.

6 Освітньо-професійна програма підготовки магістра за спеціальністю 073 “Менеджмент", освітня програма "Управління навчальним закладом". Бахмут: Навчально-науковий професійно-педагогічний інститут Української інженернопедагогічної академії, 2017. 23 с.

7 Освітньо-професійна програма підготовки магістра за спеціальністю 073 “Менеджмент", за спеціалізаціями «Бізнес-адміністрування», «Управління закладом освіти». Херсон: Херсонський державний університет, 2018. 11 с. 
The abovementioned enables us to confirm the conclusion that developing the curricula for specialty 073 "Management", specialization "Management of Educational Institution", administrators and guarantors of educational programs did not pay sufficient attention to courses related to entrepreneurial, financial, and economic activity. Although, we have repeatedly pointed out that modern education manager should always take care of the financial stability and welfare of employees in educational institution in competitive environment in educational services market.

Thus, one of the important organizational and pedagogical conditions for obtaining entrepreneurial skills results from the need of introduction into curriculum educational programs with courses covering the above specified issues, i.e. introduction of entrepreneurial professional education modules.

We identified 4 courses obligatory for all institutions of higher education offered for masters in management of educational institution.

First of all, to obtain the desired results, we need to introduce module "Entrepreneurship Culture" in the course "Management of Financial and Economic Activity". It will develop relevant students' competences due to the intensive training in solving practical economic problems that arise in daily practice of the heads of educational institutions.

Conceptually, this module should ensure the formation and development of entrepreneurial culture in future masters in management of educational institution, which in turn will result in their productivity, give their institutions financial and economic freedom, and provide profit growth through additional opportunities and means of capital accumulation. This is obviously a prerequisite for successful day-to-day managers' activities which involves communication with potential investors.

The main task of this module is to give managers a relevant vision for the future, direct them to innovation and sustainable development, improve the status of educational institution and provide its continuous updating.

Parents will also approve of the idea as they want their children to be taught by the best educators, extrapolating their life experience and knowledge, and learning conditions are important as well.

For example, landscaping, new sports grounds, recreation rooms, computer classes, etc. are also of great importance for social school 
image, as it helps to create such place where children feel comfortable and attracts social interest.

The next course to be amended is "Management of Labor Resources and Performance". The introduction of module "Methods of Motivation and Stimulation of Personnel" for masters of specialty 073 "Management", educational program - "School Management" is essential to train them in modern means of stimulation and motivation of personnel. As practice shows, the issue of motivation is always a priority if it is aimed at increasing the income of any enterprise, or there is a need to replenish the potential of the enterprise through internal reserves, such as creativity of business entities, their responsibility for the results of their performance.

We agree with O.V.Zemka's opinion, who said that "positive motivation of modern entrepreneurship is not limited to purely financial interests and needs, and is as a complex of socio-economic and personalvalue orientations, which direct the activities of entrepreneur to the channel of increasing the material by enhancing its competitive advantages and overcoming deficiencies, implementing new ambitious ideas for developing its own business and implementing socially significant projects. It involves the choice of independent activity for achieving economic independence and self-improvement of material well-being, realization of beliefs and leadership potential, based on a conscious internal desire of the individual for professional and social self-realization"8.

Creating by managers supportive motivational environment and effective system of assessing their subordinates' performance gives them opportunity to make their interests meet the interests of educational institutions.

Another important course under study "Head of Educational Institution and Management Psychology" should include module "Psychology of Entrepreneurship".

Thus, effective influence on subordinates' performance requires from managers understanding of psychological mechanisms of human behavior.

8 Земка О. В. Формування підприємницької компетентності в майбутніх учителів технологій у процесі професійної підготовки : дис....канд. пед. наук: 13.00.04. Глухів, 2018. 340 с. 
Clearly defined and well-known to each teacher requirements, rewards for their achievements, valuable to teachers, dependence of teachers' status on their team performance, objectivity of results evaluation, appropriate requirements to teachers, fairness in rewards distribution - all these are important conditions for the productive work of subordinates.

Regarding educational institution as an enterprise with life-forms typical for any organization suggests that the content of the manager's work should include an understanding of situational tasks, namely: labor division between the members of administrative, teaching and maintenance staff, taking into account functional duties in school statute; professional training of school employees, their individual psychological characteristics; abilities to work creatively; interest in their own and school successes; ability to work collectively; ability to manage a team of teachers in accordance with official duties; ability to adhere to professional ethics.

We should also keep in mind that efficiency and coherence of managers' performance is greatly influenced by the relations between the employees. Therefore, managers' professional and psychological qualities are equally important, as they charge positively their teams.

These and other examples and arguments confirm the view of powerful prospects of introduction financial and economic component into professional training of future masters in management, which should create substantive basis for our courses - lectures or practical classes. Thus, the courses and modules introduced are as follows:

- Course "Management of Financial and Economic Activity" will include module "Entrepreneurship Culture",

- Course "Social and environmental safety of activities" will cover module "Property Insurance and Liability to Third Parties",

- Course "Management of Labor Resources and Performance" will include module "Methods of Motivation and Stimulation of Personnel",

- Course "Head of Educational Institution and Psychology of Management" will cover module "Psychology of Entrepreneurship". 


\section{Leadership in Practical Training of Managers in Education Institutions}

In the conditions of social and political instability in Ukraine, the number of educational managers who "feel at a loss" is increasing, i.e. managers, who lose usual set of targets and are not able to give appropriate response to numerous problems, financial and economic in particular.

At the end of the twentieth century, the problem was latent, it didn't affect heads' formal status and authority. In socialist society, money and material values were declared in general as minor things, excessive personal and communal enrichment was subjected to merciless public criticism. And only recently there have appeared real needs and formal claims to those managers who are not able to provide sufficient material wealth and financial support for their educational institution.

On the way to achieving such financial and economic well-being, according to the conclusions of the majority of experts of informal education of entrepreneurs, there is a problem of lack of leadership skills of current executives and insufficient attention to their formation in future specialists. Obviously, managers, who are capable of conducting powerful autonomous financial and economic policy, are those individuals our Ukrainian pedagogical teams need to rely on in recession. Consequently, there is a new important "option", ignored by most scholars by this time.

Thus, according to D. V. Alfimova, "efficient leader" is a person who has a significant influence on the behavior of group members, a person, who plans, organizes, and controls subordinates' performance in order to solve the tasks assigned to the group, giving them their vision of the future and helping them adapt to the new environment ${ }^{9}$.

Unfortunately, the definition lacks any mention of unpredictable nature of modern managers' activities, and we believe that entrepreneurial culture should be considered in the structure of leadership.

The opinions of other authors on leadership can be divided into several vectors, in which emphasis is placed on the achievement of

9 Алфімов Д. В. Зміст феномену «лідерські якості особистості». Педагогіка формування творчої особистості у вищій $i$ загальноосвітній школах. Запоріжжя, 2010. Вип. 11 (64). С. 44-51. 
common goal, though the main problem of current leaders of educational institutions - poverty and economic stagnation is shamelessly silencing:

- leadership is related to the influence on people, pursuing the achievement of a common goal (G. Kunts and S. O'Donnel);

- leadership is a force that facilitates the formation of the ability of groups of people to do something better realizing a common goal (S. M. Sobol);

- leadership is the ability to rise above the situation, to see and appreciate the overall picture, as well as the ability to organize people to achieve a common goal (Mary Parker Follett).

The following scholars attribute leadership in their essence and form to the phenomenon of power, emphasize moral and human qualities, and are more philosophical:

- leadership is a form of power, because it suggests the ability of one person to force others to do something positive or negative that they would not do or eventually could not do at all (J. Blondel);

- leadership is management at a higher level, the process of achieving meaningful results with respect, care and honesty for the wellbeing of all participants (O. Bila);

- leadership is achievement of humanity that is completely natural, without which the shifts, improvements and competitiveness of individuals in civil society and human civilization as a whole will be impossible (O. Polisaiev).

The abovementioned results in at least two conclusions. The first concerns the idea that leadership is not common to all managers, and the second - in the general outline of this phenomenon, almost no scholar distinguishes financial and economic component or competence.

For these reasons, the appeal to classic pedagogical school, who have been working out for many years the characteristics of successful teachers, teachers and managers in education, gives grounds for reflection and effective use of the already developed algorithms and schemes for the formation of the necessary set of knowledge, skills, practical skills and values of the participants of pedagogical processes.

In particular, let us pay attention to the methodical ideas of the prominent Ukrainian philosopher in the field of education I. A. Ziaziun ${ }^{10}$.

10 Педагогічна майстерність: Підручник / І. А. Зязюн, Л.В.Крамущенко, I. Ф. Кривонос та ін.; За ред. І. А. Зязюна. 3-тє вид. допов. і переробл. К. : СПД Богданова А.М., 2008. 376 с. 
The author articulated his philosophical principles, suggesting certain recommendations among pedagogical skills related to the leadership component of educators and managers in the field of education:

1) in each minor task, you should see a great purpose that in terms of financial and economic activity provides careful and respectful attitude to any material, economic or financial "victory" of institution, ability to build on this basis a fascinating "vision" of future success and prosperity;

2) optimistic forecasting is of utmost importance, as success requires positive mood to self-improve, dream of financially independent future, work for the future and be a leader;

3) leaders should be responsible for their influence, as each action entails consequences (both positive and negative), and leaders "have their cross to bear" and they should react with dignity.

It is clear, therefore, that among the qualities of modern successful leaders, material financial and economic skills take precedence over moral or humanistic. Thus, these skills should be included in the general picture of professional competences and occupy top positions. At the empirical level, such a generalization becomes more and more promising, because the overall managers style of leadership should be a model of entrepreneurship, innovation and risk aversion; a model of efficient organization and performance profitable in the market of educational services.

It is obvious that future managers can acquire relevant leadership qualities provided they get realistic practical experience through taking independent managerial decisions in the field of financial and economic relations of the institution.

Therefore, such experience should be provided to undergraduates of specialty 073 - Management (Educational Program - Management of Educational Institution) in the framework of practical training and internship. In the role of heads of structural unit, future Masters develop organizational, communicative, entrepreneurial abilities, taking responsibility for management decisions and "immersing" in the area of unfamiliar business. Thus, competences of utmost importance are as follows: stress tolerance, initiative, creativity, humanity, determination, ambition, mobility. Students work out and apply their own approaches to solving tasks, consider alternatives, evaluate their own capabilities, which should have positive result and will be reflected in the financial 
and economic "picture" of educational institution and determines strategies for the future.

A preliminary analysis of the feasibility of implementing this idea indicates that most heads of educational institutions do not allow students to act in administrative and managerial positions freely, as it is always risky. Frequently, masters are charged with responsibilities that do not require risky actions (as a rule, these are paper tasks, secretarial, routine work, typical actions and transactions limited by traditional system). Analysis of practice and internship of future masters in specialty 073 "Management" makes it possible to conclude that students have no possibility to practice taking independent management business decisions.

Another problem is that it is easier to get positive assessment for practical training and internship than real experience. The fact is that heads of educational institutions are often not motivated to provide efficient internship and rarely build realistic professional relationships with undergraduate students, except when students are already working in managerial positions at the institution and study part-time. In such cases, "connections" help to get an excellent internship reference without "extra effort".

The abovementioned arguments allow us to confirm the need to improve the practical training and internship, enhance both students' and teachers' motivation, by expanding the rights of graduate students, giving them a cautious permission for short-term domination in the team. But how can this be done in the realities of Ukrainian tradition, when future specialists merely imitate management activity in schools without any possibility of real influence on the staff or procedural aspect? Another problem is to insure future specialists against failures and gross mistakes at the stage of their actual start of professional manager's career.

The main idea in this regard is strengthening of the role of personal and official links between guarantors of educational programs, scientific and pedagogical staff of graduate departments with their graduates who have already become leaders in the market of educational services, occupy top positions of managers of educational institutions or work in public administration in the sphere of education.

In such cases, between participants in practical training and internship, there is a special type of relationship that is governed by a 
non-imperative, democratic approach based on a high degree of trust and influence. In fact, educational subculture creates conditions "to immerse competitors in professional activity", tests them from different sides and angles, and at the same time corrects patterns of professional activity or rejects people who are not able to lead pedagogical teams.

The formal side of such relationships is any interaction on the basis of cooperation agreements, which allows collective work (scientific conferences, round tables, participation in city projects aimed at identifying potential leaders of educational institutions, etc.), immersing future managers in the real environment, providing efficient interaction with experienced specialists in management.

An example of such interaction giving possibility to discover leadership qualities can be the project "Personnel Reserve of One Hundred Managers in Education for Zaporizhzhia", which allowed dozens of talented and promising young pedagogues to maximize their capacities and show their potential due to fair competition and transparent conditions.

There are other examples of cooperation on the basis of trusting relationships, mutually beneficial conditions, where the function of the head of educational institution is to create conditions for the adaptation of a young specialist due to personal interest. The interest is in the prospects of recruiting a young specialist who has already been tested and adapted to specific conditions. Leaders in this case willingly explain, teach and generously share their own experience in financial and economic sphere for further cooperation.

In such a model, students are also eager to participate and cooperate with experienced managers, since in the future they will apply for work in this educational institution. Such a trainee will be perceived as a prospective employee, potential head of a structural unit, and not as a competitor to the position of director. According to our observations, this kind of interaction will lead to mutual trust and respect (team spirit) in which both parties are interested in positive result and sustainable partnership.

Considering practical training and internship as a medium enabling to discover leadership, initiative and responsibility in the financial and economic field of future specialists, we would like to draw your attention to the need for prior awareness and knowledge of interns in the following topics: 
- enterprise as an entity (definition, goals and activity core, legal bases of functioning);

- management and structure (concepts and functions of management, general, organizational and production management);

- external environment of management (influence of external environment of enterprises, establishments and organizations (in the field of education and vocational training), macro environment and its factors, market and its economic entities);

- resources (personnel, labor productivity, production funds basic and circulating, intangible resources and assets, financial resources, investments);

- activities (innovative processes, production process and its organization, infrastructure);

- planning and motivation (state economic regulation, planning of enterprise activity, motivation and payment of labor);

- results and efficiency of production (production, quality, cost of production, financial results, integral efficiency).

Efficient practical application of knowledge and skills regarding the listed topics during practical training and internship is a guarantee of readiness for the FEA, but its logical conclusion should be summing up and personal reflection.

This procedure looks like self-examination of performance and evaluation of the decisions taken by a trainee in different situations. Trainees present reports on their practical training and internship. The main key to success of reflexive phase of practice and internship is adequate assessment of strengths and ability to accept critical remarks from head and teacher of the institution of higher education, willingness for further self-development, career development and constant selfimprovement of business manager.

The following idea, which is relevant in reference to leadership during practical training and internship, is students' academic mobility, in our case we deal with students getting their master's degree. According to the Law of Ukraine "On Higher Education", academic mobility is an opportunity for participants in the educational process to study, teach, practice or pursue scholarly activities in another institution of higher education (academic institution) on the territory of Ukraine or abroad ${ }^{11}$.

11 Закон України “Про вищу освіту” від 01.01.2019 № 1556-18. URL: http://zakon3.rada.gov.ua/laws/show/1556-18/page5_(дата звернення: 18.02.2019). 
For these purposes, there is a large range of international student exchange programs with EU countries and US Department of State programs, for example: Exchange for Future Leaders (FLEX), Teachers' Teacher Training Program (TEC), G. Humphrey Program, AIESEC Scholarships for Students, SUSI for Student Leaders, Erasmus + Program Guide, etc. In all of these programs, great attention is paid to leadership in education, economic development in the field of education management, planning and management.

The most valuable for our study is the international program Erasmus +, which offers opportunities to stimulate entrepreneurial skills, creativity, innovation in education and business. In the section "Alliances of Knowledge" the emphasis is on developing entrepreneurial mindset and skills:

- creation of a framework for the acquisition of transversal skills and their application in tertiary curricula developed in cooperation with enterprises, aimed at efficient employment, creativity and new professional trends;

- studying entrepreneurship incorporated in any discipline to provide students, researchers, academic and teaching staff with knowledge, skills and motivation to participate in entrepreneurial activity;

- opening new learning opportunities through practical application of entrepreneurial skills, which may lead to commercialization of new services, products and prototypes, startups, etc. ${ }^{12}$.

The potential of these programs is great, they offer possibility of doing 2-12 month traineeships abroad, stimulate critical thinking and promote innovative ideas, though, unfortunately, their extrapolation to Ukrainian realities is rather challenging.

Analyzing the above-mentioned programs, we face a number of problems: applicants willing to get master's degree in management (Educational Program "Management of an educational institution") are adult or elderly people. Meanwhile, most programs have age limitations for their participants. In fact, project developers see target audience as 1st-3rd year students getting their bachelor's degree, which can be explained by the policy of European Union countries giving priority to young students' emigration. This process, alongside with the decision on

${ }^{12}$ Міжнародна програма Еразмус +. URL: http://erasmusplus.org.ua/erasmus/ ka2-proekty-spivpratsi/aliansy-znan.html_(дата звернення: 18.02.2019). 
visa-free regime between the countries of the European Union, is gaining popularity. The only obstacle on the way to undergraduates' emigration is their poor knowledge of English, English language proficiency is a prerequisite for all programs. Even masters majoring in management of educational institution lack the course of Foreign Language in their curriculum, and don't have a possibility to improve their foreign language skills. It should be noted that the problem can be solved gradually through systematic work of English language agents, a network of certified English language courses, which prove the applicants' knowledge with the certificates.

The abovementioned arguments and facts about practice and internship of masters majoring in management (Specialty 073 Management, Educational Program - Management of Educational Institution) in the field of Financial and Economic relations and a brief outline of international expertise prove the necessity to include certain pedagogical features in professional training of masters: stimulating the development of leadership traits (initiative, responsibility) in contextbased practical training and internship of future Masters in school management.

\section{CONCLUSIONS}

As can be seen from the above, professional training of future managers of educational institutions is one of the priority issues. Efficient managers should possess not only administrative skills, but also have relevant expertise and skills in solving problems in financial and economic sphere, be able to apply their knowledge. In view of this, it is necessary to improve the process of training at higher school in general and future managers training in particular.

The presented arguments demonstrate the need to modify professional program for future masters majoring in management (Specialty "Management", Educational Program "Management of Educational institution") Amendments, offered by the author, i.e. introduction of certain modules, will allow to see the prospects for forming entrepreneurial competence in future specialists. After all, all managers' activities should be directed towards saving, multiplication and accumulation of material wealth through enhancing competitive advantages of their institutions in the market of educational services and overcoming shortcomings, implementing new ambitious ideas for 
developing their own business and implementing socially significant projects.

Leadership life-style settings of future managers of educational institutions are developed in the process of practical training and internship. Pilot pedagogical experiment has shown that graduate students starting their careers as heads of educational institutions face a number of difficulties, which become a barrier to their further steady progress. They are as follows:

- impossibility of rapid adaptation to the new environment;

- lack of resistance when under attack, pressure from authority (including teachers, parents, heads of structural units);

- poor awareness of the role of manager in financial and economic sphere;

- lack of creative ideas for improving the territory;

- lack of involvement and interest in the chosen profession.

In spite of all of the above-mentioned problems, young and ambitious leaders often successfully adapt to the environment, they obtain a desire to do their best and at a high level, they get involved in the process and direct all their efforts to create the ideal conditions for the functioning, development and prosperity of educational institution.

Only on condition of these goals activated, modern educational institutions will update their priorities, focus on financial and economic sphere and improve it in general.

\section{SUMMARY}

The research presents mechanisms and means of training future masters majoring in management of educational institutions. The main focus is on their financial and economic activity.

It was stated that taking advantage of academic freedom in building professional training programs Specialty 073 "Management" (Educational Program - Management of Educational Institution), institutions of higher education significantly reduced, and sometimes completely abandoned such disciplines as "Management of Financial and Economic Activity" and "Audit and Evaluation of Management Performance", which for a long time were mandatory in the professional training. The courses were excluded from the curricular in favor of purely pedagogical and administrative subjects. It was proved by the analysis of educational and professional programs developed in Semen 
Kuznets Kharkiv National University of Economics; Ukrainian Engineering and Pedagogical Academy; Kherson State University and others.

We suggest curricula reforming, i.e. introduction of certain modules that provide cognitive basis for future heads of educational institutions in financial and economic sphere. These changes are as follows: course "Management of Financial and Economic Activity" should contain module "Entrepreneurship Culture", course "Social and Environmental Safety" should include module "Property Insurance and Responsibility to Third Parties", course "Management of Labor resources and Performance" should cover module "Methods of Personnel Motivation and Stimulation", and course "Head of Educational Institution and Psychology of Management" should include module "Psychology of Entrepreneurship".

It is proved that the formation of leadership qualities in future masters majoring in management (Specialty "Management", Educational Program "Management of Educational Institution") depends on obtaining relevant practical experience through the adoption of independent managerial decisions in the field of financial and economic relations of the institution. The main area for such a guarantee is practical training and internship of graduate students, when the official opportunity is given to plunge into the plane of unfamiliar but productive work with the possibility to take financial and economic decisions.

It is emphasized that managers are capable of conducting powerful autonomous financial and economic policy and they are those individuals who Ukrainian pedagogical teams are willing to rely on to overcome recession.

The main challenges of practical training and internship in modern educational institutions are highlighted and ways of solving the problems and dealing with complications are presented.

The issues of academic mobility of students and the list of international programs for exchanging students of the European Union and programs of the State Department of the United States, which allow getting international experience, promote innovative ideas for the economic independence of educational institutions and their development, are listed. In spite of great potential of these programs, there is a number of difficulties Ukrainian people and future masters in management are facing and they are analyzed in our research. 


\section{REFERENCES}

1. Освітньо-професійна програма підготовки магістра за спеціальністю специфічних категорій 8.000009 "Управління навчальним закладом”. Київ: Міністерство освіти і науки України, $2016.61 \mathrm{c}$.

2. Освітньо-професійна програма підготовки магістра за спеціальністю 073 "Менеджмент". Харків: Харківський національному економічному університеті імені Семена Кузнеця, 2016. 79 c.

3. Про особливості запровадження переліку галузей знань i спеціальностей, за якими здійснюється підготовка здобувачів вищої освіти: наказ Міністерства освіти і науки від 06.11.2015 №1151 України 2015 року № 266. URL: https://imzo.gov.ua/2015/11/06/ nakaz-mon-vid-6-11-2015-1151-pro-osoblivosti-zaprovadzhennya-perelikugaluzey-znan-i-spetsialnostey-za-yakimi-zdiysnyuyetsya-pidgotovkazdobuvachiv-vishhoyi-osviti-zatverdzhenogo-postanovoyu/

(дата звернення: 30.07.2018).

4. Освітньо-професійна програма «Управління навчальним закладом» за спеціальністю 073 «Менеджмент». Київ: Національний університет біоресурсів і природокористування України, 2018. 28 с.

5. Освітньо-професійна програма підготовки магістра за спеціальністю 073 "Менеджмент", освітня програма "Управління навчальним закладом". Бахмут: Навчально-науковий професійнопедагогічний інститут Української інженерно-педагогічної академії, 2017.23 c.

6. Освітньо-професійна програма підготовки магістра за спеціальністю 073 "Менеджмент", за спеціалізаціями «Бізнесадміністрування», «Управління закладом освіти». Херсон: Херсонський державний університет, 2018. 11 с.

7. Земка О. В. Формування підприємницької компетентності в майбутніх учителів технологій у процесі професійної підготовки : дис....канд. пед. наук: 13.00.04. Глухів, 2018. 340 с.

8. Алфімов Д. В. Зміст феномену «лідерські якості особистості». Педагогіка формування творчої особистості у вищій $i$ загальноосвітній школах. Запоріжжя, 2010. Вип. 11 (64). С. 44-51.

9. Педагогічна майстерність: Підручник / I. А. Зязюн, Л. В. Крамущенко, І. Ф. Кривонос та ін.; За ред. І. А. Зязюна. 3-те вид. допов. і переробл. К. : СПД Богданова А.М., 2008. 376 с. 
10. Закон України “Про вищу освіту” від 01.01.2019 № 1556-18. URL: http://zakon3.rada.gov.ua/laws/show/1556-18/page5 (дата звернення: 18.02.2019).

11. Міжнародна програма Еразмус +: URL: http://erasmusplus.org.ua/erasmus/ka2-proekty-spivpratsi/aliansyznan.html (дата звернення: 18.02.2019).

Information about the author: Kuzmenko Yu. A. Assistant Professor, Department of Education and Management of Educational Institution, Classical Private University 70b, Zhukovskoho str., Zaporizhia, 69002, Ukraine 